\title{
Maternal Exposure to High Temperatures Disrupts OCT4 mRNA Expression of Rabbit Pre-Implantation Embryos and Endometrial Tissue
}

\author{
F Marco-Jiménez ${ }^{1}$, C Naturil-Alfonso ${ }^{1}$, DS Peñaranda ${ }^{1}$, E Jiménez-Trigos ${ }^{1}$, FJ García-Diego ${ }^{2,3}$ and JS Vicente $^{1}$ \\ ${ }^{1}$ Institute of Science and Animal Technology (ICTA), Universitat Politècnica de València, Valencia, Spain; ${ }^{2}$ Department of Applied Physics \\ (U.D. Agrónomos), Universitat Politècnica de València, Valencia, Spain; ${ }^{3}$ Centro de Tecnologías Físicas, Unidad Asociada ICMM-CSIC/UPV, \\ Universitat Politècnica de València, Valencia, Spain
}

\section{Contents}

We examined the effect of prolonged high heat stress on reproductive performance and its relationship with gene expression in pre-implantation embryos and endometrial tissue. In experiment 1, primiparous rabbit does were divided into two environments: control does (maintained between 14 and $22^{\circ} \mathrm{C}$ ) and heat-treated does housed in a climatic chamber (maintained between 25 and $35^{\circ} \mathrm{C}$ ). Females were reproducing, and the litter size and live born kits were assessed at 2nd and 3rd partum. In heat-treated does, lower litter size $(9.7 \pm 0.48$ and $11.4 \pm 0.50)$ and fewer live born kits $(7.2 \pm 0.55$ and $10.2 \pm 0.57)$ were observed, although similar ovulation rates and numbers of pre-implantation embryos were noted. In experiment 2, after 3rd partum multiparous non-lactating does from each experimental group were used to obtain preimplantation embryos and endometrial tissue. mRNA transcripts from OCT-4, VEGF, erbB3, Ifn-,$H S P 70$ and HSP90 were analysed by real-time qPCR. Higher values of $O C T-4$ expression were observed in embryos and endometrial tissue in females reproduced under heat conditions. Moreover, elevated temperatures have been shown to up-regulate $V E G F$ in embryos and down-regulate If $n-\gamma$ in endometrial tissue. The findings suggest a deleterious temperature effect on litter size and live born kits as a consequence of variation in gene expression pattern of the pre-implantational embryo and the endometrium associated with proliferation and differentiation and probably with implantation and uterine and foetal development during gestation.

\section{Introduction}

The effect of high temperatures on rabbit doe performance has been studied by experiments carried out in summer (Méndez et al. 1986; Marai et al. 2002), creating the desired heat conditions in climatic chambers (Fernández-Carmona et al. 1995, 2003) or artificially under in vitro culture of oocytes and embryos (Alliston et al. 1995; Makarevich et al. 2007). Heat stress causes alterations in the biological processes and functions (Hansen 2009).

Among heat effects in females, the main alteration is a feed intake reduction. Therefore, some metabolites would not be available for metabolism disturbing enzymatic reactions, hormones and blood composition (Wittroff et al. 1998; Marai et al. 2002). Heat stress thus alters several aspects of reproductive physiology, such as blood flow and steroidogenesis (Roman-Ponce et al. 1978; Trout et al. 1998; Rivera and Hansen 2001), which manifests in fertility alterations. It is widely accepted that the traits mainly affected by heat stress in females are puberty, ovulation rate, conception rate, implantation and embryonic development and viable embryos per doe, litter size, litter weight, milk-produc- tion and pre- and post-weaning mortality (Marai et al. 2002).

Heat stress during pregnancy results in changes in endocrine dynamics of the maternal unit due to disturbances in the activity of the hypothalamo-pituitaryadrenocortical axis (HPA) and sympatho-adrenal medullary axis (Minton 1994). Modification of these glands causes changes in endocrine profiles of hormones such as cortisol and corticosterone, epinephrine, triiodothyronine and thyroxine, oestrone sulphate, progesterone, aldosterone, glucocorticoids and catecholamines (Thompson et al. 1963; Collier et al. 1982; Magbud et al. 1982; Minton 1994; Kumar et al. 2011). This hormonal dysfunction has been reported to cause lower birth weights, reduced conceptus function, delay in foetal growth, miscarriage, stillbirths and consequently reduced fertility in females (Collier et al. 1982; Bell et al. 1989; Malayer et al. 1990; Kumar et al. 2011). In addition, an elevation of body temperature affects uterine environment by decreasing blood flow, responsible for providing nutrients, oxygen and water to the developing embryo, ovary, cervix and oviduct (Senger et al. 1967; Bazer et al. 1969; Roman-Ponce et al. 1978; Lubin and Wolfenson 1996; García-Ispierto et al. 2006). These maternal body alterations due to heat stress have been shown to cause important disturbances at different stages of embryonic development, such as cleavage and blastocyst formation (Wolfenson and Blum 1988; Rivera and Hansen 2001; Matsuzuka et al. 2005). Reduced embryo development is not just a consequence of body temperature, but also of the interaction between embryo and uterine environment (Ozawa et al. 2002; Matsuzuka et al. 2005).

The current study examines the effect of prolonged high heat stress, as occurs in summer in the Mediterranean area, on reproductive performance and its relationship with gene expression in pre-implantation embryos and endometrial tissue.

\section{Materials and Methods}

All chemicals in this study were purchased from SigmaAldrich Química S.A. (Madrid, Spain) unless stated otherwise.

\section{Animals}

Rabbit does belonging to Line $\mathrm{V}$ from the ICTA at Polytechnic University of Valencia (Spain) were used to obtain embryos. The V line is selected for litter size at weaning (Estany et al. 1989). The Ethics and Animal 
Welfare Committee of the Universidad Politécnica de Valencia approved this study. All animals were handled according to the principles of animal care published by Spanish Royal Decree 1201/2005 (BOE, 2005; $\mathrm{BOE}=$ Official Spanish State Gazette).

In this study, rabbit does were divided into two groups: control $\left(14-22^{\circ} \mathrm{C}\right)$ and heat-treated $\left(25-35^{\circ} \mathrm{C}\right)$ does. In the heat-treated group, does were housed in a climatic chamber $(13 \times 4.7 \times 3.1 \mathrm{~m})$ of $175 \mathrm{~m}^{3}$ of air (García-Diego et al. 2011). In this chamber, animals were maintained with sinusoidal curve in a range of 25 to $35^{\circ} \mathrm{C}$ and humidity range from $11.8 \%$ to $63.8 \%$, reaching the minimum at $12 \mathrm{p} . \mathrm{m}$. and maximum at 12 a.m. (García-Diego et al. 2011). In the control group, does were housed in a conventional room with temperatures varying between 14 and $22^{\circ} \mathrm{C}$ and a humidity range from $28.8 \%$ to $65.2 \%$. The actual summer and winter conditions of the Spanish Mediterranean area were reproduced in both experimental groups.

\section{Experimental design}

In this study, two sequential experiments were conducted. In experiment 1 , litter size and number of kits born alive from heat-treated females were assessed and compared with the control group. In experiment 2, mRNA expression of OCT-4, VEGF, erbB3, Ifn-y, $H S P 70$ and HSP90 on pre-implantation embryos and endometrial tissue for heat-treated females was assessed and compared with control group samples.

Experiment 1. Reproductive performance under high temperature conditions

In this experiment, a total of 22 heat-treated does and 20 control does were used. Heat-treated females were acclimated to climatic chamber during 1st partum. During 2nd and 3rd partum, the female's reproductive behaviour was reported. Both groups of does were artificially inseminated when receptive (identified by red vulvar lips) with pooled sperm, using a standard curved plastic pipette (Imporvet, S.A., Barcelona, Spain). At the same time, each female was given an intramuscular injection of $1 \mu \mathrm{g}$ of buserelin acetate to induce ovulation. Litter size and number of kits born alive during 2nd and 3rd partum were reported.

\section{Experiment 2}

In this experiment, after the 3rd partum, 11 multiparous non-lactating does from each group were artificially inseminated as previously described, $48 \mathrm{~h}$ after synchronization with 25 UI of PMSG (Foligon ${ }^{\circledR}$; Intervet, Boxmeer, Holland). Then, females were slaughtered 6 days post-artificial insemination. Reproductive tracts were dissected, and ovulation rates were recorded. Embryos were recovered by flushing of uterine horns with $20 \mathrm{ml}$ of DPBS (Dulbecco's phosphate-buffered saline) supplemented with $0.1 \%$ of BSA. The number of pre-implantational embryos recovered for each female was noted. In addition, endometrium samples were obtained from each female by gently scraping. Samples were stored at $-20^{\circ} \mathrm{C}$ in RNA later solution (Qiagen Iberia SL, Madrid, Spain) until RNA extraction.

\section{Total RNA extraction and cDNA synthesis}

Total RNA was isolated from 13 different pools consisting of six to ten pre-implantational embryos (6 for control group and 7 for heat-treated group). The gene expression for endometrial tissue was performed in 17 females $(8$ for control group and 9 for heat-treated group). Total RNA was isolated by traditional phenol/chloroform method using sonication in reagent Trizol (Invitrogen S.A, Barcelona, Spain). To prevent DNA contamination, one deoxyribonuclease treatment step (gDNA Wipeout Buffer, Qiagen Iberia SL) was performed from total RNA. Afterwards, $1 \mu \mathrm{g}$ of total RNA isolated from preimplantational embryos and endometrial tissue was reverse transcribed into cDNA in a total volume of $20 \mu 1$ using QuantiTect Reverse Transcription Kit (Qiagen Iberia SL), following the manufacturer's instructions.

\section{Primers design}

Two genes, histone (H2afz) and glyceraldehyde-3-phosphate dehydrogenase $(G A P D H)$, were selected as reference genes in the quantitative RT reverse transcriptase-polymerase chain reaction (qRT-PCR) in accordance with Llobat et al. (2011). BESTKEEPER (version 1) software was used to analyse the stability of both reference genes (Pfaffl et al. 2004). Furthermore, gene specific primers were assayed to evaluate $O C T-4$, vascular endothelial growth factor $(V E G F)$, epidermal growth factor receptor-3 (erbB3), interferon-gamma $(I f n-\gamma)$, and heat shock protein 70 and 90 (HSP70, HSP90) expression (Table 1). Specific primers were designed exon to exon for HSP70 and HSP90 gene expression (Table 1). All primers have efficiency between 86 and 110 and a correlation between 0.986 and 0.999 in both tissues. Genomic DNA and total RNA (pool from embryos) samples were run to check possible amplification. To avoid DNA contamination, DNA and RNA samples were run to check possible amplification. The products of real-time PCR were confirmed by ethidium bromide-stained $2 \%$ agarose gel electrophoresis in $1 \times$ TBE buffer.

\section{SYBR Green assay (qPCR)}

The mRNA expression was analysed by real-time PCR in an Applied Biosystems 7500 (Applied Biosystems, Foster City, CA, USA). PCR was performed from diluted $(1: 10)$ cDNA template. Five microlitre of each sample was used in each reaction in a final volume of $20 \mu \mathrm{l}$ with $10 \mu \mathrm{l}$ of $2 \times$ SYBR Green Master Mix (Thermo Scientific, Fisher Scientific, Madrid, Spain), $250 \mathrm{~nm}$ of forward and reverse primers (list of real-time PCR primers is shown in Table 1). The PCR protocol included an initial step of $50^{\circ} \mathrm{C}(2 \mathrm{~min})$, followed by $95^{\circ} \mathrm{C}(10 \mathrm{~min}), 42$ cycles of $95^{\circ} \mathrm{C}(1 \mathrm{~s})$ and $60^{\circ} \mathrm{C}(1 \mathrm{~min})$. After real-time PCR, a melting curve analysis was performed by slowly increasing the temperature from $65^{\circ} \mathrm{C}$ to $95^{\circ} \mathrm{C}$, with continuous recording of changes in fluorescent emission intensity. Serial dilutions of cDNA 
Table 1. Primer sequence, accession number, amplicon size obtained, efficiency, correlation and reference where indicated, of genes analysed and housekeeping genes used (OCT-4, transcript of POU5F1 gene; $V E G F$, as vascular endothelial growth factor; Inf- $y$, as interferon-gamma; $e r b B 3$, as epidermal growth factor receptor 3; HSP70, as heat shock protein 70; HSP90, as heat shock protein 90; histone (H2afz) and glyceraldehyde-3phosphate dehydrogenase (GAPDH), as housekeeping gene)

\begin{tabular}{|c|c|c|c|c|}
\hline Gene & Accession number & Sequence & Fragment size $(\mathrm{pb})$ & Reference \\
\hline$O C T 4$ & NM_001099957 & $\begin{array}{l}\text { For - 5'CGAGTGAGAGGCAACTTGG } \\
\text { Rev - CGGTTACAGAACCACACACG }\end{array}$ & 125 & Mamo et al. (2008) \\
\hline$V E G F$ & AY196796 & $\begin{array}{l}\text { For }-5^{\prime} \text { CTACCTCCACCATGCCAAGT } \\
\text { Rev }-5^{\prime} \text { CACACTCCAGGCTTTCATCA }\end{array}$ & 236 & Saenz-de-Juano et al. (2011) \\
\hline Inf- $y$ & NM_001081991 & $\begin{array}{l}\text { For - 5'GTCTGCATTCTAGCCACTG } \\
\text { Rev - 5'ATTCAGGGGCAGTCACAGTT }\end{array}$ & 151 & Llobat et al. (2011) \\
\hline erbB3 & AF333179 & $\begin{array}{l}\text { For - 5'GTCACATGGACACGATCGAC } \\
\text { Rev - 5'AAGCAGTGGCCGTTACACT }\end{array}$ & 191 & Saenz-de-Juano et al. (2011) \\
\hline HSP70 & 100354037 & $\begin{array}{l}\text { For }-5^{\prime} \text { GGAAGCACAAGAAGGACCTG } \\
\text { Rev }-5^{\prime} \text { CCTGGTGATGGACGTGTAGA }\end{array}$ & 158 & \\
\hline HSP90 & ENSOCUT00000013430 & $\begin{array}{l}\text { For - 5'AGAGGTTCCTGCACCATGAG } \\
\text { Rev - 5'TTCCCGCTCCATAAAAAGTG }\end{array}$ & 177 & \\
\hline H2afz & AF030235 & $\begin{array}{l}\text { For - 5'AGAGCCGGCTGCCAGTTCC } \\
\text { Rev - 5'CAGTCGCGCCCACACGTCC }\end{array}$ & 85 & Mamo et al. (2008) \\
\hline$G A P D H$ & L23961 & $\begin{array}{l}\text { For - 5'GCCGCTTCTTCTCGTGCAG } \\
\text { Rev - 5'ATGGATCATTGATGGCGACAACAT }\end{array}$ & 144 & Navarrete-Santos et al. (2004) \\
\hline
\end{tabular}

pool made from several samples were run in triplicate to asses PCR efficiency and decide which dilutions to use for unknown samples. A $\Delta \Delta C_{\mathrm{t}}$ method adjusted for PCR efficiency was used (Weltzien et al. 2005), employing as normalization factor the geometric average of $H 2 a f z$ and $G A P D H$. Target and reference genes in unknown samples were run in duplicate. Relative expression of cDNA pool from all samples was used as a calibrator. Nontemplate control (cDNA was replaced by water) for each primer pair was run in all plates.

\section{Statistical analysis}

Total litter size, number of kits born alive, ovulation rate and 6-day-old embryos recovered were analysed by oneway ANOVA, using the general linear models (GLM) procedure of STATGRAPHICS PLUS 5.1 (STSC Inc., Rockville, MD, USA). For mRNA expression, differences in mRNA expression among different groups in each comparison were also analysed by one-way ANOVA, using the GLM procedure. For HSP90 and HSP70 in endometrial tissue, a Neperian logarithmic transformation was carried out before analysis for data normalization. Differences of $\mathrm{p}<0.05$ were considered significant.

\section{Results}

\section{Experiment 1}

Litter size and number of kits born alive reported to be different between heat-treated and control group females, being lower in does submitted to heat treatment than in control group (Table 2).

\section{Experiment 2}

Ovulation rate and pre-implantation embryo recovery

Ovulation rate did not show significant differences between heat-treated and control group females (Table 3). In the same line, the number of pre-implantation embryos recovered from heat-treated and control group females was also similar (Table 3 ).
Table 2. Litter size, number of kits born alive for heat-treated and control group females (mean $\pm \mathrm{SEM}$ )

\begin{tabular}{llrr}
\hline Experimental group & $\mathrm{n}$ & Litter size & Live born kits \\
\hline Heat treatment & 22 & $9.7 \pm 0.48^{\mathrm{b}}$ & $7.2 \pm 0.55^{\mathrm{b}}$ \\
Control & 20 & $11.4 \pm 0.50^{\mathrm{a}}$ & $10.2 \pm 0.57^{\mathrm{a}}$ \\
\hline
\end{tabular}

Different superscripts in the same column represent a significant difference $(\mathrm{p}<0.05)$.

$\mathrm{n}$, number of females used.

Table 3. Ovulation rate and pre-implantation embryos recovered for heat-treated and control group females (mean \pm SEM)

\begin{tabular}{llcc}
\hline Experimental group & $\mathrm{n}$ & Ovulation rate & Recovered embryos \\
\hline Heat treatment & 11 & $17.8 \pm 1.15$ & $12.5 \pm 1.47$ \\
Control & 11 & $16.6 \pm 1.70$ & $11.8 \pm 2.18$ \\
\hline
\end{tabular}

$\mathrm{n}$, number of females used.

\section{$m R N A$ expression}

The expression level of HSP90 in pre-implantation embryos was too low to obtain a correct efficiency curve to work with, so the analysis of mRNA expression of this gene was dismissed only for embryos. BestKeeper showed that both $H 2 a f z$ and GAPDH are stable in preimplantation embryos and endometrial tissue ( 0.60 vs 0.53 and 0.65 vs 0.53 , for pre-implantation embryos and endometrial tissue, respectively). The geometric average of both was therefore used as reference.

Differences in mRNA transcript abundance between pre-implantation embryos and endometrial tissue in both conditions are shown in Figs 1 and 2. In preimplantational embryos, the level of expression of $O C T$ 4 and $V E G F$ was higher for heat-stressed females $(1.27 \pm 0.06$ vs $0.89 \pm 0.09$ and $2.50 \pm 0.25$ vs $1.12 \pm 0.35$, for heat-stressed and control females, respectively). No differences were detected for Inf- $\gamma$, erbB3 and HSP70.

According to previous results in pre-implantational embryos, in endometrial tissue, OCT-4 expression also 


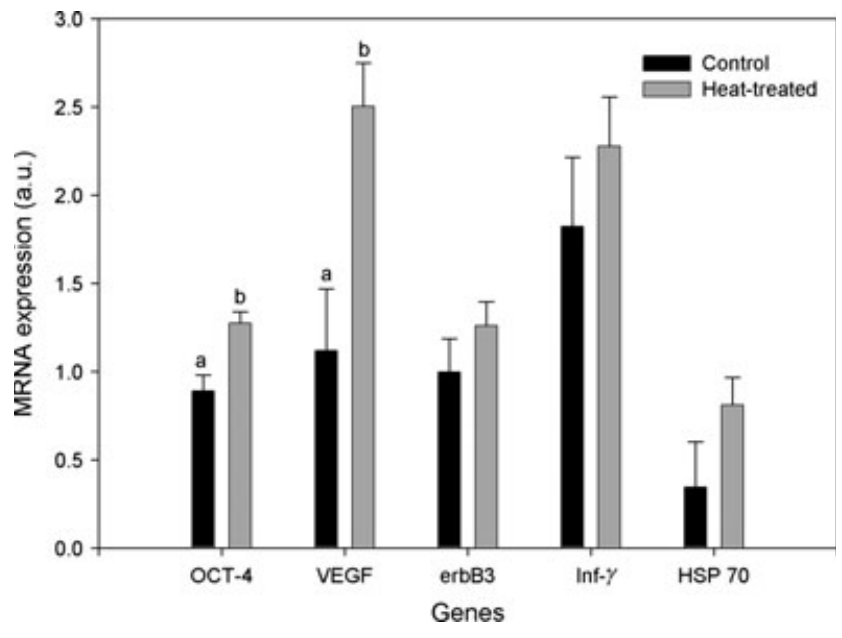

Fig. 1. Relative expression of transcription factor $O C T-4$, vascular endothelial growth factor $(V E G F)$, epidermal growth factor receptor 3 (erbB3), Inf- $y$, interferon-gamma and heat shock protein 70 (HSP70) for pre-implantation embryo of control and heat-treated females. Relative abundance values are expressed by the mean value $\pm \mathrm{SEM}$ of the replicates of each group. a.u.: arbitrary units. Bars with different letters are significantly different $(\mathrm{p}<0.05)$

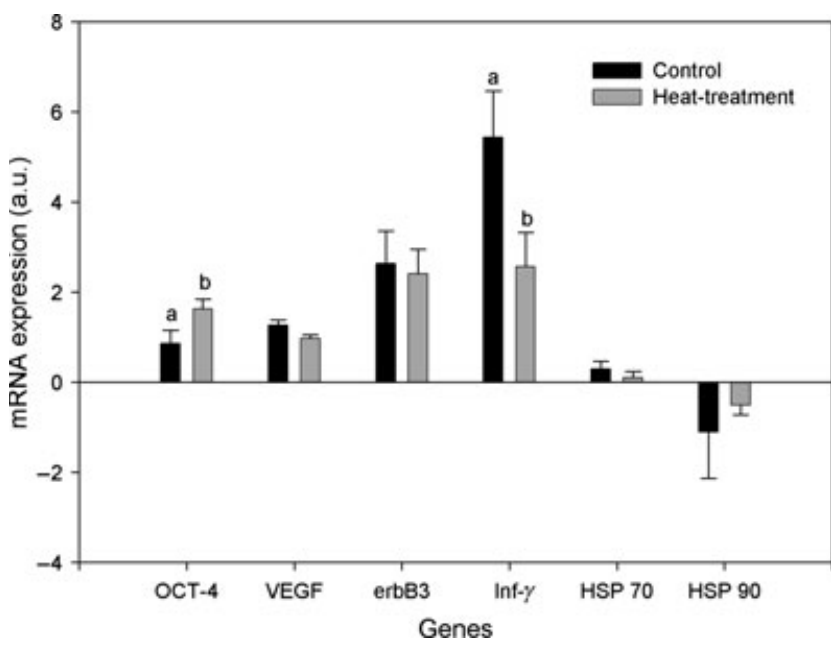

Fig. 2. Relative expression of transcription factor $O C T-4$, vascular endothelial growth factor $(V E G F)$, epidermal growth factor receptor 3 (erbB3), Inf- - , interferon-gamma, heat shock protein 70 (HSP70), heat shock protein 90 (HSP 90) for endometrial tissue of control and heattreated females. Relative abundance values are expressed by the mean value \pm SEM of the replicates of each group. a.u.: arbitrary units. Bars with different letters are significantly different $(p<0.05)$

showed higher values for heat-treated than for control females $(1.63 \pm 0.21$ vs $0.86 \pm 0.29)$. On the other hand, If $n-\mathrm{y}$ reported lower expression in heat-treated than in control females $(5.43 \pm 1.03$ vs $2.56 \pm 0.76)$. The level of expression of HSP90, VEGF, erbB3 and HSP70 was similar between both groups of females in this tissue.

\section{Discussion}

It is widely known that high temperatures lead to a decrease in fertility and prolificacy (Wolfenson et al. 2000; Marai et al. 2002; De Rensis and Scaramuzzi 2003; Hansen 2009). The current study indicates that the adverse effect of high temperatures on reproductive performance is associated with variation in the gene expression of embryos and endometrial tissue before the implantation, but not with a reduced ovulation rate, fecundation rate or proportion of embryos developing to the late blastocyst stage. The findings of this study indicate similar numbers of recovery pre-implantation embryos, as previously reported (Edwards et al. 1968; Omtvedt et al. 1971). Nevertheless, several studies in rabbit and other mammalian species have shown that high temperature causes a reduction in the litter size (Marai et al. 2002; Fernández-Carmona et al. 2003). It has also been demonstrated that reduction in litter size is approxiamtely 14\% (current study) and in line with previous reports (Ayyat and Marai 1998). This decline seems to be associated with the implantation process, as studies pre- and post-implantation in heat-stressed females have shown a drop in the number of implantations and viable embryos after this process (Alliston et al. 1965; Omtvedt et al. 1971; Wolfenson and Blum 1988). Omtvedt et al. (1971) established that heat stress still has a great effect on foetal mortality during late gestation in gilts. However, Edwards et al. (1968) reported that embryos are less susceptible to heat stress after implantation. Nevertheless, studies carried out with embryos under in vitro conditions showed less development to the blastocyst stage when embryos were exposed to heat stress at 1 cell stage and 2 cell stage, but when in vivo early development was assessed, the same number of implantations was reported (Alliston et al. 1965; Rivera and Hansen 2001; Matsuzuka et al. 2005).

Heat stress has been documented to induce alterations in the transcriptional levels of genes involved in cell growth, cell cycle and programmed cell death (Gasca et al. 2008). Our results provided evidence of an altered OCT-4 expression in both embryonic and endometrial tissue in females reproducing under high temperature, as previously reported (Gendelman and Roth 2011). OCT4 is regarded as a key regulator of the pluripotency maintenance system (Boiani and Schöler 2005). The main function of this transcriptional factor is to activate or repress several target genes involved in many cases in cell differentiation and early embryonic development (Smith et al. 2007). In vivo develop of rabbit embryos shown a pattern of down-regulation in OCT-4 transcripts in 5- and 6-day-old blastocysts compared to 4-day-old blastocysts, and it has been suggested as an intrinsic embryo mechanism to enable successful implantation (Saenz-de-Juano et al. 2010). Therefore, up-regulation in OCT-4 transcripts in embryos observed in our study supports the assumption that these embryos have a developmental delay. The altered expression of $O C T-4$ in pre-implantational embryo is associated with embryos of lower quality (Gendelman and Roth 2011). OCT-4 mRNA expression has been detected in human endometrial stromal (Matthai et al. 2006; Bentz et al. 2011), although to our best knowledge, expression in endometrial tissue has not been previously reported in rabbit. OCT-4 expression strongly suggests the existence of endometrial stem cells, probably in stromal, that must be able to differentiate into mesenchymal tissues, given the remarkable plasticity, regenerative capacity and growth of endometrium (Park et al. 2011). Furthermore, differ- 
ential regulation of $O C T-4$ could reflect uterus perturbations and might explain, in part, the decrease in litter size observed in heat-stressed does (current study) and in previous reports (Marai et al. 2002; Fernández-Carmona et al. 2003). In addition, Inf- $\gamma$ in endometrial tissue and $V E G F$ in pre-implantation embryos also showed altered regulation. They are related to implantation, as $V E G F$ is involved in the connection of foetal to maternal blood supplies (Cullinan-Bove and Koos 1993), and Inf- $y$ is related to pregnancy recognition (Godornes et al. 2007). In fact, previous studies have reported that $O C T-4$ affects the expression of $V E G F$ and inhibits human chorionic gonadotrophin expression (Liu et al. 1997; Yamamoto et al. 1998), which could explain the related alterations, as suggested by Llobat et al. (2011).

The expression of HSP70 in embryos and endometrial tissue and HSP9O in endometrium did not differ among heat-treated and control females. HSPs are synthesized in response to a wide variety of cellular injuries that are induced by changes in temperature as well as other stress conditions, such as the presence of free oxygen radicals, infections, heavy metals, ethanol and ischaemia (Lindquist 1986; Welch 1992). Increased HSP70 expression is associated with increased ability of the stressed cells to protect themselves from cell death (Mosser et al. 1997) by interacting with apoptotic mechanisms (Buzzard et al. 1998; Li et al. 2000; Parcellier et al. 2003). Under heat stress conditions, they have shown to activate transcription and production of HSP genes and to modify maternal hormones and uterine environment $(\mathrm{Ju}$ 2005). Specifically, mRNA expression of HSP70 has been reported to correlate with the length of heat shock to induce thermotolerance (Jia et al. 2010). Nevertheless, our results showed similar expression of HSP70 and HSP90. Thus, we can suggest that as females were allocated to the climate chamber during three partums before the mRNA expression analysis; perhaps in this period, females might have adapted to our heat conditions (Omtvedt et al. 1971). In this way, the mRNA expression of erbB3 observed, involved in cell proliferation, differentiation and apoptosis during embryo development, was similar in both groups. Despite the important role of this gene, other studies have reported constant expression in different stages of embryo development and in endometrial tissue of different rabbit lines (Saenz-de-Juano et al. 2010; Llobat et al. 2011).

Therefore, our findings suggest a deleterious temperature effect on litter size and live born kits as a consequence of induced thermotolerance response on gene expression of pre-implantational embryo and endometrium associated with proliferation and differentiation and probably with implantation and uterine and foetal development during gestation.

\section{Acknowledgements}

This work was supported by the Spanish Research Projects AGL200803274 (CICYT). Carmen Naturil was supported by Generalitat Valenciana research programme (Prometeo 2009/125). Estrella Jiménez was supported by a research grant from the Education Ministry of the Valencian Regional Government (programme VALi+d. ACIF/ 2010/262). English text version was revised by N. Macowan English Language Service.

\section{Conflict of interest}

None of the authors have any conflict of interest to declare.

\section{Author contributions}

F Marco-Jiménez, C Natural-Alfonso, E Jiménez-Trigos and JS Vicente contributed to study design, analysed data and drafted paper. DS Peñaranda supported molecular technical assistance. FJ GarcíaDiego contributed to design and control of the climatic chamber.

\section{References}

Alliston CW, Howarth B Jr, Ulberg LC, 1965: Embryonic mortality following culture in vitro of one- and two-cell rabbit eggs at elevated temperatures. J Reprod Fertil 9, 337-341

Ayyat MS, Marai IFM, 1998: Evaluation of application of intensive rabbit production system under the subtropical conditions of Egypt. J World Rabbit Sci 6, 213-217.

Bazer FW, Ulberg LC, LeMunyan CD, 1969: Altered urine environment on embryo survival. J Anim Sci 28, 144.

Bell AW, McBride BW, Sleptis R, Early RJ, Currie WB, 1989: Chronic heat stress an prenatal development in sheep: I. Concepts growth and maternal plasma hormones and metabolites. J Anim Sci 67, 3289.

Bentz EK, Kenning M, Schneeberger C, Kolbus A, Huber JC, Hefler LA, Tempfer CB, 2011: OCT-4 expression in follicular and luteal phase endometrium: a pilot study. Reprod Biol Endocrinol 22, 8-38.

Boiani M, Schöler HR, 2005: Regulatory networks in embryo-derived pluripotent stem cells. Nat Rev Mol Cell Biol 6, 872 881 .
Boletín Oficial del Estado (BOE), 2005: Rea Decreto 1201/2005. Sobre protección de los animales utilizados para experimentación y otros fines científicos. Boletin Oficial del Estado 252, 34367-34391.

Buzzard KA, Giaccia AJ, Killender M, Anderson RL, 1998: Heat shock protein 72 modulates pathways of stress induced apoptosis. J Biol Chem 273, 17147-17153.

Collier RJ, Doelger SG, Head HH, Thatcher WW, Wilcox CJ, 1982: Effects of heat stress during pregnancy on maternal hormone concentrations, calf birth weight and postpartum milk yield of Holstein Cows. J Anim Sci 54, 309-319.

Cullinan-Bove K, Koos RD, 1993: Vascular endothelial growth factor/vascular permeability factor expression in the rat uterus: rapid stimulation by estrogen correlates with estrogen-induced increases in uterine capillary permeability and growth. Endocrinology 133, 829-837.

De Rensis F, Scaramuzzi RJ, 2003: Heat stress and seasonal effects on reproduction in the dairy cow:a review. Theriogenology 60, 1139-1151.

Edwards RL, Omtvedt IT, Turman EJ, Stephens DF, Mahoney GWA, 1968 Reproductive performance of gilts follow- ing heat stress prior to breeding and in early gestation. J Anim Sci 27, 1634.

Estany J, Baselga M, Blasco A, Camacho J, 1989: Mixed model methodology for the estimation of genetic response to selection in litter size of rabbits. Livest Prod Sci 21, 62-76.

Fernández-Carmona J, Cervera C, Sabater C, Blas E, 1995: Effect of diet composition on the production of rabbit breeding does housed in a traditional building and at $30^{\circ} \mathrm{C}$. Anim Feed Sci Technol 52, 289 297.

Fernández-Carmona J, Alqedra I, Cervera C, Moya J, Pascual JJ, 2003: Effect of lucerne-based diets on performance of reproductive rabbit does at two temperatures. Anim Sci 76, 283-295.

García-Diego FJ, Oascual JJ, Marco-Jiménez F, 2011: Technical note: design of a large variable temperature chamber for heat stress studies in rabbits. World Rabbit Sci 19, 225-231.

García-Ispierto I, López-Gatius F, Santolaria $\mathrm{P}$, Yániz JL, Nogareda $\mathrm{C}$, LópezBéjar M, De Rensis F, 2006: Relationship between heat stress during the periimplantation period and early fetal loss 
in dairy cattle. Theriogenology $\mathbf{6 5}, 799-$ 807 .

Gasca S, Reyftmann L, Pellestor F, Rème T, Assou S, Anahory T, Dechaud H, Klein B, De Vos J, Hamamah S, 2008: Total fertilization failure and molecular abnormalities in metaphase II oocytes. Reprod Biomed Online 17, 772-781.

Gendelman M, Roth Z, 2011: Seasonal effect on germinal vesicle-stage bovine oocytes is further expressed by alterations in transcript levels in the developing embryo associated with reduced developmental competence. Biol Reprod 86, 1-9.

Godornes C, Leader BT, Molini BJ, Centurion-Lara A, Lukehart SA, 2007: Quantitation of rabbit cytokine mRNA by realtime RT-PCR. Cytokine 38, 1-7.

Hansen PJ, 2009: Effects of heat stress on mammalian reproduction. Philos Trans Soc B 364, 3341-3350.

Jia Y, Hartshorn C, Hartung O, Wangh LJ, 2010: Heat shock memory in preimplantation mouse embryos. Fertil Steril 93, 2760-2763.

Ju CJ, 2005: Cellular responses of oocytes and embryos under thermal stress: hints to molecular signaling. Anim Reprod 2, 70-90.

Kumar BV, Ajeet K, Meena K, 2011: Effect of heat stress in tropical livestock and different strategies for its amelioration. $\mathbf{J}$ Stress Phys Biochem 7, 45-54.

Li CY, Lee JS, Ko YG, Kim JI, Seo JS, 2000: Heat shock protein 70 inhibits apoptosis downstream of cytochrome c release and upstream of caspase-3 activation. J Biol Chem 275, 25665-25671.

Lindquist S, 1986: The heat shock response. Annu Rev Biochem 55, 1151-1191.

Liu L, Leaman DW, Villalta M, Roberts RM, 1997: Silencing of the gene for the alpha-subunit of human chorionic gonadotropin by the embryonic transcription factor Oct-3/4. Mol Endocrinol 11, 16511658.

Llobat L, Marco-Jiménez F, Peñaranda DS, Saenz-de-Juano MD, Vicente JS, 2011: mRNA expression in rabbit blastocyst and endometrial tissue of candidate gene involved in gestational losses. Reprod Domest Anim 47, 281-287.

Lubin A, Wolfenson D, 1996: Lactation and pregnancy effects in blood flow to mammary and reproductive systems in heatstressed rabbits. Comp Biochem Physiol A Physiol 115, 277-285.

Magbud A, Johnson HD, Belyea RL, 1982: Effect of environmental heat and dietary fibers on thyroid physiology of lactating cows. J Dairy Sci 65, 2323-2331.

Makarevich AV, Olexiková L, Chrenek P, Kubovicová E, Fréharová K, Pivko J, 2007: The effect of hyperthermia in vitro on vitality of rabbit preimplantation embryos. Physiol Res 56, 789-796.

Malayer JR, Hansen PJ, Gross TS, Tatcher WW, 1990: Regulation of heat shockinduced alterations in the release of prostaglandins by the uterine endometrium of cows. Theriogenology 34, 219.

Mamo S, Gal AB, Polgar Z, Dinnyes A, 2008: Expression profiles of the pluripotency marker gene POU5F1 and valida- tion of reference genes in rabbit oocytes and preimplantation stage embryos. BMC Mol Biol 9, 67.

Marai IFM, Habeeb AAM, Gad AE, 2002: Rabbits' productive, reproductive and physiological performance traits as affected by heat stress: a review. Livest Prod Sci 78, 71-90.

Matsuzuka T, Ozawa M, Nakamura A, Ushitani A, Hirabayashi M, Kanai Y, 2005: Effects of heat stress on the redox status in the oviduct and early embryonic development in mice. J Reprod Dev 51, 281-287.

Matthai C, Horvat R, Noe M, Nagele F, Radjabi A, van Trotsenburg M, Huber J, Kolbus A, 2006: Oct-4 expression in human endometrium. Mol Hum Reprod 12, 7-10.

Méndez J, De Blas JC, Fraga MJ, 1986: The effects of diet and remating interval after parturition on the reproductive performance of the commercial doe rabbit. J Anim Sci 62, 1624-1634.

Minton JE, 1994: Function of the HPA axis and Sympathetic nervous system in models of acute stress in domestic farm animals. J Anim Sci 72, 1891.

Mosser DD, Caron AW, Bourget L, DenisLarose C, Massie B, 1997: Role of HSP 70 in protection against stress-induced apoptosis. Mol Cell Biol 17, 5317-5327.

Navarrete-Santos A, Tonack S, Kirstein M, Pantaleon M, Kaye P, Fischer B, 2004: Insulin acts via mitogen-activated protein kinase phosphorylation in rabbit blastocysts. Reproduction 128, 517-526.

Omtvedt IT, Nelson RE, Edwards RL, 1971: Influence of heat stress during early, mid and late pregnancy of gilts. J Anim Sci 32 321-317.

Ozawa M, Hirabayasi M, Kanai Y, 2002: Developmental competence and oxidative state of mouse zygotes heat-stressed maternally or in vitro. Reproduction 124, 683-689.

Pfaffl MW, Tichopad A, Prgomet C, Neuvians TP, 2004: Determination of stable housekeeping genes, differentially regulated target genes and sample integrity: BestKeeper Excel-based tool using pairbase correlations. Biotechnol Lett 26, 509-515.

Parcellier A, Schmitt E, Gurbuxani S, Seigneurin-Berny D, Pance A, Chantôme A, Plenchette S, Khochbin S, Solary E, Garrido C, 2003: HSP27 is a ubiquitinbinding protein involved in I-kappaB alpha proteasomal degradation. Mol Cell Biol 23, 5790-5802.

Park JH, Daheron L, Kantarci S, Lee BS, Teixeira JM, 2011: Human endometrial cells express elevated levels of pluripotent factors and are more amenable to reprogramming into induced pluripotent stem cells. Endocrinology 152, 1080-1089.

Rivera RM, Hansen PJ, 2001: Development of cultured bovine embryos after exposure to high temperatures in the physiological range. Reproduction 121, 107-115.

Roman-Ponce H, Thatcher WW, Canton D, Barron DH, Wilcow CJ, 1978: Thermal stress effects on uterine blood flow in dairy cows. J Anim Sci 46, 175-180.
Saenz-de-Juano MD, Peñaranda DS, Marco-Jiménez F, Llobat L, Vicente JS, 2010: Differential mRNA expression in rabbit in vivo pre-implantatory embryos. Reprod Domest Anim 46, 567-572.

Saenz-de-Juano MD, Naturil-Alfonso C, Vicente JS, Marco-Jiménez F, 2011: Effect of different culture systems on mRNA expression in developing rabbit embryos. Zygote 15, 1-7.

Senger PL, Lose ED, Ulberg LC, 1967 Reduced blood supply to the uterus as a cause for early embryonic death in the mouse. J Exp Zool 165, 337.

Smith C, Berg D, Beaumont S, Standley NT, Wells DN, Pfeffer PL, 2007: Simultaneous gene quantitation of multiple genes in individual bovine nuclear transfer blastocyst. Reproduction 133, 231-242.

Thompson RD, Johnson JE, Breidensten CP, Guirdy AJ, 1963: Effect of hot conditions on adrenal cortical, thyroidal and other metabolic responses of diary heifers. J Dairy Sci 46, 277.

Trout JP, McDowell LR, Hansen PJ, 1998 Characteristics of the estrous cycle and antioxidant status of lactating Holstein cows exposed to heat stress. J Dairy Sci 81, 1244-1250.

Welch YJ, 1992: Mammalian stress response: cell physiology, structure/function of stress proteins, and implications for medicine and disease. Physiol Rev 72, 1063-1080.

Weltzien FA, Pasqualinib C, Vernierb P, Dufoura S, 2005: A quantitative real-time RT-PCR assay for European eel tyrosine hydroxylase. Gen Comp Endocrinol 142, 134-142.

Wittroff EK, Heird CE, Rakes JM, Johnson ZB, 1998: Growth and reproduction of nutrient restricted rabbits in a heatstressed environment. J Appl Rabbit Res 11, 87-92.

Wolfenson D, Blum O, 1988: Embryonic development, conception rate, ovarian function and structure in pregnant rabbits heat-stressed before or during implantation. Anim Reprod Sci 17, 59-270.

Wolfenson D, Roth Z, Meidan R, 2000: Impaired reproduction in heat-stressed cattle: basic and applied aspects. Anim Reprod Sci 60/61, 535-547.

Yamamoto H, Flannery ML, Kupriyanov S, Pearce J, McKercher SR, Henkel GW, Mari RA, Werb Z, Oshima RG, 1998: Defective trophoblast function in mice with a targeted mutation of Ets2. Genes Dev 12, 7883-7891.

\section{Submitted: 18 Apr 2012; Accepted: 3 Sep} 2012

Author's address (for correspondence): Francisco Marco Jiménez, Laboratory of Biotechnology of Reproduction, Institute of Science and Animal Technology (ICTA) at the Polytechnic University of Valencia, C/Camino de Vera s/n, 46022 Valencia, Spain. E-mail: fmarco@dca.upv.es 